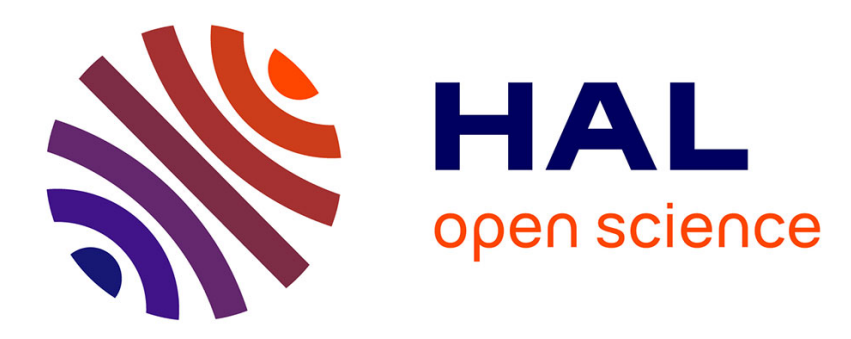

\title{
Growth Stability in Semiopen Physical Vapour Transport
}

\author{
C. Paorici, M. Zha, L. Zanotti, L. Carotenuto, T. Tiberti
}

\section{To cite this version:}

C. Paorici, M. Zha, L. Zanotti, L. Carotenuto, T. Tiberti. Growth Stability in Semiopen Physical Vapour Transport. Journal de Physique IV Proceedings, 1995, 05 (C5), pp.C5-1053-C5-1060. 10.1051/jphyscol:19955124 . jpa-00253820

\section{HAL Id: jpa-00253820 https://hal.science/jpa-00253820}

Submitted on 1 Jan 1995

HAL is a multi-disciplinary open access archive for the deposit and dissemination of scientific research documents, whether they are published or not. The documents may come from teaching and research institutions in France or abroad, or from public or private research centers.
L'archive ouverte pluridisciplinaire HAL, est destinée au dépôt et à la diffusion de documents scientifiques de niveau recherche, publiés ou non, émanant des établissements d'enseignement et de recherche français ou étrangers, des laboratoires publics ou privés. 


\title{
Growth Stability in Semiopen Physical Vapour Transport
}

\author{
C. Paorici, M. Zha*, L. Zanotti*, L. Carotenuto** and T. Tiberti** \\ Physics Dept., Univ. of Parma, 43100 Parma, Italy \\ * MASPEC-CNR Institute, 43100 Parma, Italy \\ ** MARS-Center, 80125 Naples, Italy
}

\begin{abstract}
An interface stability model is proposed for crystal growth by physical vapour transport (PVT) in semiopen (SO) systems, which is based on the constitutional supercooling criterium. The model, whose main feature is the relaxation of the local eqilibrium assumption at the growing interface, proved suitable for explaining the remarkable growth stability in SO systems when applied to urea growth. A semiempirical approach for estimating the pressure inside a SO-system and the kinetic contributions to stability is also proposed, which allows for quantitative comparison of model and experimental results.
\end{abstract}

\section{INTRODUCTION}

Physical vapour transport (PVT) has been used for growing large-size crystals, many of which are interesting substrate materials for electronic devices [1]. Usually, PVT growth processes are carried out in closed cells (ampoules) in which a polycrystalline source is sublimated at a given temperature and made to condense (crystallize) at a lower temperature at a distance L from the source [2-3].

A modification of these closed-cell configurations makes use of semiopen (SO) cells vented to vacuum through suitable leakages[1-4].

In spite of technical complications, the SO configurations have significant advantages: 1) decrease of undesired volatile impurities, with lowering of diffusional barriers; hence purer crystals grown at a faster growth rate; 2 ) more flexibility, as the overall pressure (P) is now a new degree of freedom, while in closed configurations it is a fixed temperature-dependent quantity; 3) crystals grown by SO-PVT techniques usually exhibit a higher degree of interface (morphological) stability as compared to crystals grown in closed systems.

This third point, which has never been stressed in previous works, will be here analyzed and discussed with reference to urea crystals. Urea is an important non-linear optics material $[5,6]$ which has been grown by SO-PVT [7], obtaining crystals with high structural perfection and remarkably good morphological stability [8] at bias with what observed when growing crystals in closed configurations.

For these reasons, urea is a suitable model substance for studying the interface stability in both closed and SO-PVT systems.

In this paper, an analysis of interface stability based on the constitutional supercooling criterium, as previously developed for PVT growth in closed configurations [9-12], is extended to include SO-PVT processes. However, in order to account for the strong kinetic limitations in urea growth, the local equilibrium approximation of previous works has been relaxed. 


\section{ANALYSIS OF INTERFACE STABILITY CONDITIONS}

Urea PVT is based on the following chemical reactions $[8,13]$ :

$$
\begin{aligned}
& U_{(s)} \Leftrightarrow U_{(g)} \\
& 2 U_{(s)} \Leftrightarrow A_{(g)}+B_{(s)}
\end{aligned}
$$

in which $\mathrm{U}$, $\mathrm{A}$ and $\mathrm{B}$ stand for urea $\left(\mathrm{NH}_{2} \mathrm{CONH}_{2}\right)$, ammonia $\left(\mathrm{NH}_{3}\right)$ and biuret $\left(\left[\mathrm{NH}_{2} \mathrm{CO}\right]_{2} \mathrm{NH}\right)$ and subscripts (s) and (g) stand for "solid" and "gaseous".
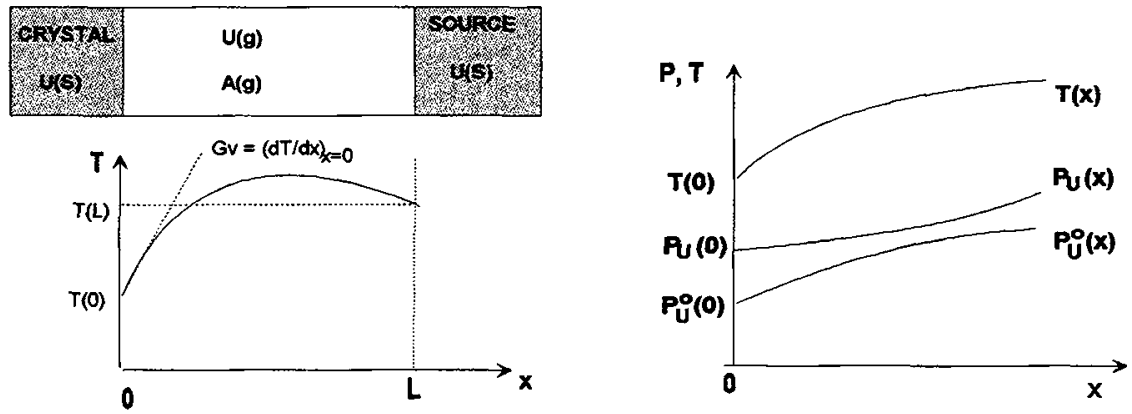

Figure 1: PVT arrangement with temperature profile $T(x)$ and actual and equilibrium partial pressure profiles $P_{U}(x)$ and $P_{U}{ }^{0}(x)$ at and ahead of the growing interface; $P_{U}(0)-P_{U}{ }^{0}(0)$ at $x=0$ scales the kinetic constraints at the growing interface.

With reference to Fig. 1, reaction (1) occurs at $x=0, L$ while reaction (2) only takes place at $x=L$, where $\mathrm{x}=0$ and $\mathrm{x}=\mathrm{L}$ are the locations of the growing and subliming (flat) interfaces respectively.

In order to relax the local equilibrium assumption of previous analyses, a more general stability criterium is used, which predicts stability only when the supersaturation gradient $\nabla_{\mathrm{x}} \sigma \leq 0$ at $\mathrm{x}=0$. As previously shown [3], this is equivalent to give the stability condition as

$$
\mathrm{v}_{\mathrm{U}(\mathrm{s})} \leq \frac{\mathrm{D}_{298}^{0}}{\mathrm{C}_{\mathrm{U}(\mathrm{s})} \mathrm{RR}_{0}}\left(\frac{\mathrm{T}}{298}\right)^{1.8} \frac{\left[\Delta \mathrm{H}_{\mathrm{U}}-\mathrm{RT}(0)\right]}{\mathrm{T}^{3}(0)}\left\{\frac{\mathrm{P}_{\mathrm{U}}(0)}{\mathrm{P}-\mathrm{P}_{\mathrm{U}}(0)}\right\} \mathrm{G}_{\mathrm{v}}
$$

in which $v_{U(s)}$ is the average linear growth rate; $\mathrm{D}_{298}^{0}$ is the binary diffusion coefficient of urea and ammonia at $298 \mathrm{~K}$ and $1 \mathrm{~atm} ; 2 \overline{\mathrm{T}}=\mathrm{T}(\mathrm{L})+\mathrm{T}(0) ; \mathrm{C}_{\mathrm{U}(\mathrm{s})}$ is the molar density of solid urea; $\mathrm{G}_{\mathrm{v}}=$ temperature gradient at $\mathrm{X}=0 ; \mathbf{R}$ and $\mathrm{R}_{0}$ are the gas constant in different units; $\Delta \mathrm{H}_{\mathrm{U}}$ and $\Delta \mathrm{S}_{\mathrm{U}}$ are the enthalpy and entropy changes associated to reaction (1) respectively; $T(0)$ and $\mathrm{Pu}(0)$ are the temperature and actual pressure of urea in $x=0$ (growing interface) respectively. As heat transport is assumed not to be rate limiting, while mass transport is, $T(0)$ is practically conciding with the equilibrium temperature of the interface while $P_{U}(0)$ differs from the equilibrium value $P_{U}{ }^{0}(0)$, as indicted in Fig. 1 . As previously shown[3], $P_{U}(0)$ and $P_{U}{ }^{0}(0)$ are related by

$$
P_{U}(0)=P_{U}^{0}(0)+\left(\frac{R_{0} T(0) C_{U(s)}}{k_{R}}\right) v_{U(s)}
$$

in which $k_{R}$ is a kinetic constant given by

$$
\mathrm{k}_{\mathrm{R}}=\frac{\mathrm{fR}_{0} \mathrm{~T}(0) \alpha}{\sqrt{2 \pi \mathrm{M}_{\mathrm{U}} \mathrm{RT}(0)}}
$$

In eq. (5), $f=$ unit conversion factor; $M_{U}=$ molecular weight of urea; $\alpha(\leq 1)=$ condensation (crystallization) coefficient. 
Inequality (3) gives the stability condition in terms of a critical growth rate that cannot be exceeded. However, as $P_{U}(0)$ is also a function of $v_{U}(s)$, by replacing $P_{U}(0)$ in (3) with its expression (4), we obtain the new stability condition:

$$
B_{2}\left[v_{U(s)}\right]^{2}+B_{1}\left[v_{U(s)}\right]+B_{0} \geq 0
$$

in which

$$
\begin{aligned}
B_{0} & =P_{u}^{0}(0) G_{v}\left\{\frac{\Delta H_{U}-R T(0)}{R T^{2}(0)}\right\} \\
B_{1} & =R_{0} C_{U(s)}\left\{\frac{G_{v}\left[\Delta H_{U}-R T(0)\right]}{k_{R} R T(0)}-\frac{T(0)\left[P-P_{U}^{0}(0)\right]}{D_{298}^{0}(\bar{T} / 298)^{1.8}}\right\} \\
B_{2} & =\frac{\left[C_{U(s)} R_{0} T(0)\right]^{2}}{D_{298}^{0}(\bar{T} / 298)^{1.8}}
\end{aligned}
$$

From (6), we have stability only when

$$
\mathrm{v}_{\mathrm{U}(\mathrm{s})} \leq \mathrm{v}_{\mathrm{CRTT}}, \quad \mathrm{v}_{\mathrm{U}(\mathrm{s})} \geq \mathrm{v}^{\prime}{ }_{\mathrm{CRTT}}
$$

in which $\mathrm{v}_{\text {CRTT }} \geq \mathrm{v}_{\mathrm{CRTT}}$.

At constant pressure, these two critical growth rates are in relation with two different vapour compositions, the former characterized by $P_{U}(0)<P_{A}(0)$, the latter by $P_{U}(0)>P_{A}(0)$,. This latter case, that can in principle be achieved in a CVD reactor, is impossible with our closed and SO-PVT urea growth processes and will no further be considered.

As to $v_{U(s)}$ in (10), it has previously been shown [3] that in the assumption of local equilibrium at $\mathrm{x}=\mathrm{L}$, we can write:

$$
\mathrm{V}_{\mathrm{U}(\mathrm{s})}=\frac{\mathrm{P}_{\mathrm{U}}^{0}(\mathrm{~L}) / \mathrm{T}(\mathrm{L})-\mathrm{P}_{\mathrm{U}}^{0}(0) / \mathrm{T}(0)}{\mathrm{C}_{\mathrm{U}(\mathrm{s})} \mathrm{R}_{0}\left\{\frac{1}{\mathrm{k}_{\mathrm{R}}}+\frac{\mathrm{L}\left(\mathrm{P}-\mathrm{P}_{\mathrm{U}}^{0}(\mathrm{~L})\right)}{\mathrm{D}_{298}^{0}(\overline{\mathrm{T}} / 298)^{1.8}}\right\}}
$$

\section{STABILITY CONDITIONS AND COMPARISON WITH EXPERIMENTS}

By comparing $\mathrm{v}_{\mathrm{U}(\mathrm{s})}$ with its critical values (for calculations the input data are in Table 1), it can be seen that stability increases with $\mathrm{G}_{\mathrm{v}}$, as in melt growth [17]. But, more specifically to vapour growth, stability is also the result of (a) low $P$, which explains the remarkable stability in SO-PVT growth and (b) the presence of kinetic limitations, i.e, small values of $k_{R}$ and hence of $\alpha$.

Table 1: The input data for calculations

\begin{tabular}{|lll|}
$\mathrm{R}=1.98 \mathrm{cal} / \mathrm{K} \times \mathrm{mol}$ & $\Delta \mathrm{H}_{\mathrm{U}}=20950 \mathrm{cal} / \mathrm{mol}[14]$ & $\mathrm{C}_{\mathrm{U}(\mathrm{s})}=0.022 \mathrm{~mol} / \mathrm{cm}^{3}$ \\
$\mathrm{R}_{\mathrm{o}}=82.057 \mathrm{~atm} \times \mathrm{cm}^{3} / \mathrm{K} \times \mathrm{mol}$ & $\Delta \mathrm{S}_{\mathrm{U}}=34.59 \mathrm{cal} / \mathrm{K} \times \mathrm{mol}[14]$ & $\mathrm{D}_{298}=0.13 \mathrm{~cm}^{2} / \mathrm{sec}^{(*)}$ \\
$\mathrm{f}=155.4 \mathrm{~g}^{1 / 2} \mathrm{cal}^{1 / 2} / \mathrm{cm}^{2} \times \mathrm{sec} \times \mathrm{atm}$ & $\Delta \mathrm{H}_{\mathrm{A}}=63100 \mathrm{cal} / \mathrm{mol}[13]$ & $\mathrm{M}_{\mathrm{U}}=60$ \\
& $\Delta \mathrm{S}_{\mathrm{A}}=160 \mathrm{cal} / \mathrm{K} \times \mathrm{mol}$ [ [13] & $\mathrm{M}_{\mathrm{A}}=17$ \\
\hline
\end{tabular}

$\left(^{*}\right)$ Estimated from Chapman-Enskog kinetic theory data $[15,16]$ 
This is evident in Fig.2. For given temperature conditions $\left(T(L), T(0), G_{v}\right)$ and source-crystal distance (L), the instability conditions fall within a region whose boundary is approximately parabolic, which is so much the wider the greater $\alpha$ is, being maximum for $\alpha=1$. Also reported for comparison is the stability limit as calculated assuming local equilibrium $\left(\mathrm{P}_{\mathrm{U}}(0)=\mathrm{P}_{\mathrm{U}}{ }^{0}(0)\right)$, which predicts more instability in the low$\alpha$, low-P region.

\section{1. $P$ and $\alpha$ in a closed system}

In a closed system the overall pressure $P$ is approximately given by

$$
P=\frac{P(L)}{T(L)}\left\{\frac{1}{L} \int_{0}^{L} T(x) d x\right\}
$$

in which: $\mathrm{P}(\mathrm{L}) \sim \mathrm{P}_{\mathrm{U}}^{0}(\mathrm{~L})+\mathrm{P}^{0}{ }_{\mathrm{A}}(\mathrm{L}) ; \mathrm{T}(\mathrm{x})$ is a parabolic $\mathrm{T}$-profile defined by $\mathrm{T}(\mathrm{L}), \mathrm{T}(0)$ and $G_{V} ; P_{A}^{0}(L)$ is given by an Arrhenius relationship provided that $\Delta \mathrm{H}_{\mathrm{A}}$ and $\Delta \mathrm{S}_{\mathrm{A}}$ are known.

As to $\alpha$, estimates can be given by comparing experimental and calculated values of $\mathrm{v}_{\mathrm{U}(\mathrm{s})}[13]$.

\section{2 $\mathrm{P}$ and $\alpha$ in a semiopen system}

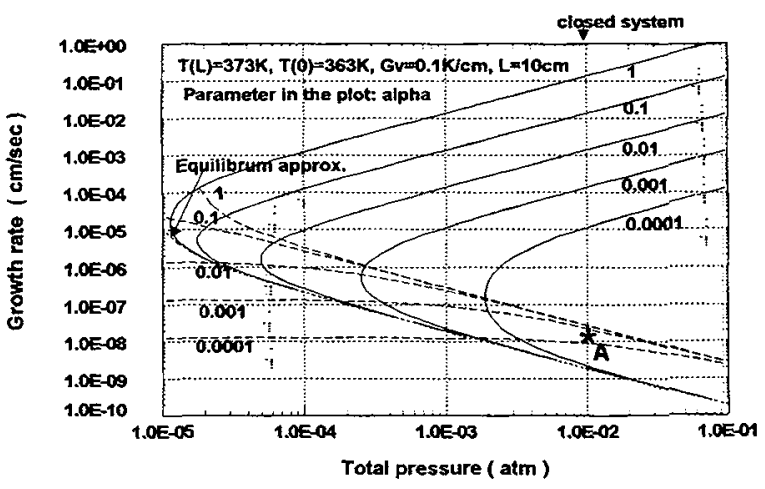

Figure 2: Growth rate (dashed curves) and critical growth rate (solid curves) against $P$ for different $\alpha$-values; critical conditions in local-equilibrium approximation also indicated; $P$ and experimental value of $\mathrm{V}_{U(s)}$ for a closed configuration is also given (*, point $A$ ).

The actual pressure within an operating

SO ampoule is largely arbitrary as it depends not only on $\mathrm{T}(\mathrm{x})$ and the geometry of the effusion leakage, but also on the external pressure $\left(\mathrm{P}_{\mathrm{ext}}\right)$. Its estimate, as well as that of $\alpha$, can be achieved semiempirically, prior to a SO-PVT growth experiment, through flux balances in the assumption of incompressible vapours and experimental measurements of crystallization and effusion fluxes.

The flux balance can be written:

$$
\sum_{j} Q_{i}^{j}=0 \quad i=A, U ; \quad j=S, H, C
$$

in which $\mathrm{j}$ stands for interface location $(\mathrm{S}=$ source, $\mathrm{x}=\mathrm{L} ; \mathrm{C}=$ crystal; $\mathrm{x}=0$ ) and effusion-hole location $(\mathrm{H})$; indexes $\mathrm{i}$ and $\mathrm{j}$ can apply to any other relevant quantity ${ }^{(*)}$.

The flux $Q_{i}^{j}[\mathrm{~g} / \mathrm{sec}]$, which is negative when entering the gaseous volume of the ampoule $\left(\mathrm{Q}_{i}^{\mathrm{S}}\right)$ and positive $\left(\mathrm{Q}_{i}^{\mathrm{C}}, \mathrm{Q}_{i}^{\mathrm{H}}\right)$ when leaving it, can be written:

$$
Q_{i}^{j \times H}= \pm k_{i}^{j} S^{j}\left(P X_{i}^{j}-\left(P_{i}^{0}\right)^{j}\right) \text {. }
$$

in which $X_{i}^{j}$ is the molar fraction of the $i-t h$ component in the $j$-th location; $S$ is the area of the solidvapour interface in the $j$-th location when $j=S, C$ and the leakage area when $j=H$; in SO-ampoules it can be assumed that $S^{C}=S^{S}=\pi r^{2}$, $r$ being the ampoule cross-section radius; $k_{1}^{j}$ is a kinetic constant given by:

$$
\mathrm{k}_{\mathrm{i}}^{\mathrm{j} \neq \mathrm{H}}=\mathrm{f} \alpha_{\mathrm{i}}^{\mathrm{j}} \sqrt{\frac{\mathrm{M}_{\mathrm{i}}}{2 \pi R T^{\mathrm{j}}}}
$$

The effusion flux of the $i$-th component is

$$
Q_{i}^{H}=\mathbf{k}^{\mathrm{H}} \mathbf{S}^{\mathrm{H}} \mathbf{X}_{i}^{\mathrm{H}} \sqrt{\mathbf{M}_{\mathrm{i}}}\left(\mathbf{P}-\mathrm{P}_{\text {ext }}\right)
$$

in which the kinetic-like constant is given by

${ }^{(*)} \mathrm{T}^{\mathrm{j}},\left(\mathrm{P}_{\mathrm{i}}^{\mathrm{o}}\right)^{\mathrm{i}}$ are equivalent notations of $\mathrm{T}(\mathrm{x}), \mathrm{P}_{i}^{\circ}(\mathrm{x})$; e.g., $\mathrm{T}^{\mathrm{s}}=\mathrm{T}(\mathrm{L}),\left(\mathrm{P}_{i}^{\circ}\right)^{\mathrm{c}}=\mathrm{P}_{\mathrm{i}}^{\circ}(0)$, etc. 


$$
\mathrm{k}^{\mathrm{H}}=\frac{\gamma \mathrm{f}}{\sqrt{2 \pi \mathrm{RT}^{\mathrm{H}}}}
$$

The quantity $\gamma$ in (17) is related to the expect ratio (h/a) of a cylindrical effusion hole of radius $a$, drilled in an ampoule wall of thickness $h$, by[1]:

$$
\gamma=\frac{1+0.4(\mathrm{~h} / \mathrm{a})}{1+0.95(\mathrm{~h} / \mathrm{a})+0.15(\mathrm{~h} / \mathrm{a})^{2}}
$$

The assuption of an incompressible vapour phase under steady-state effusion conditions, further requires the same overall density $\left(\rho^{j}\right)$ to hold for all locations, so we write

$$
\rho^{S}=\rho^{H}=\rho^{C}
$$

This is obviously an approximation, as $\rho^{\mathrm{j}}$ depends on $\mathrm{T}^{\mathrm{j}}$, but it can be justified by the small temperature variations $\left(2 \div 10^{\circ} \mathrm{C}\right)$ and low pressure $(\mathrm{P}<10$ torr $)$ involved.

Since we can also write

$$
\rho^{j}=\sum_{i} \rho_{i}^{j}=\frac{P}{R_{0}} \sum_{i} \frac{X_{i}^{j} M_{i}}{T^{j}}
$$

From (19) and (20) we obtain

$$
X_{U}^{j}=\frac{M_{A}}{M_{U}-M_{A}} X_{U}^{H} \frac{T^{j}}{T^{H}}\left(\frac{T^{j}}{T^{H}}-1\right), \quad j=S, C
$$

Now, from (13) (14) and (16) one gets:

$$
\sum_{j \neq H} k_{i}^{j} S^{j}\left[\left(P_{i}^{\circ}\right)^{j}-P X_{i}^{j}\right]=k^{H} S^{H} X_{i}^{H} \sqrt{M_{i}}\left(P-P_{e x t}\right), \quad i=U, A
$$

\begin{tabular}{|c|c|c|c|c|c|c|c|c|}
\hline No. & $\begin{array}{l}\mathrm{T}^{\mathrm{C}} \\
\left({ }^{\circ} \mathrm{C}\right)\end{array}$ & $\begin{array}{l}\mathrm{T}^{\mathrm{S}} \\
\left({ }^{\circ} \mathrm{C}\right)\end{array}$ & $\begin{array}{c}\mathrm{Q}_{\mathrm{EXP}}^{\mathrm{H}} \\
(\mathrm{mg} / \mathrm{hr})\end{array}$ & $\underset{(\mathrm{mg} / \mathrm{hr})}{\left[\mathrm{Q}_{\mathrm{U}}^{\mathrm{C}}\right]_{\mathrm{EXP}}}$ & $\begin{array}{c}\mathrm{a} / \mathrm{h} \\
(\mathrm{mm} / \mathrm{mm})\end{array}$ & $\underset{\text { (mbar) }}{\mathrm{P}_{\mathrm{EXT}} \times 10^{3}}$ & $\begin{array}{l}\mathrm{P} \times 10^{3} \\
\text { (mbar) }\end{array}$ & $\alpha_{U}^{c} \times 10^{2}$ \\
\hline 1 & 90 & 100 & 0.097 & 25.74 & $0.1 / 1.5$ & 10 & 77 & 2.63 \\
\hline 2 & 90 & 97 & 0.079 & 15.13 & $0.1 / 1.5$ & 7.5 & 63 & 2.46 \\
\hline 3 & 90 & 94 & 0.068 & 9.08 & $0.1 / 1.5$ & 7.5 & 55 & 2.90 \\
\hline 4 & 85 & 90 & 0.070 & 6.62 & $0.1 / 1.5$ & 7.5 & 59 & 2.45 \\
\hline 5 & 90 & 100 & 0.171 & 27.00 & $0.15 / 1.5$ & 8.0 & 44 & 2.66 \\
\hline 6 & 90 & 97 & 0.150 & 15.70 & $0.15 / 1.5$ & 7.5 & 40 & 2.36 \\
\hline 7 & 90 & 94 & 0.130 & 8.18 & $0.15 / 1.5$ & 7.0 & 36 & 2.53 \\
\hline 8 & 85 & 90 & 0.100 & 6.9 & $0.15 / 1.5$ & 7.0 & 29 & 2.39 \\
\hline
\end{tabular}

Relations (21) and (22), taking into account the constraint

$$
\sum_{i} X_{i}^{j}=1, \quad i=A, U ; j=S, H, C
$$

give a set of four independent equations in the eight unknowns $X_{U}^{S}, X_{U}^{H}, X_{U}^{C}, P, \alpha_{U}^{S}, \alpha_{U}^{C}, \alpha_{A}^{s}, \alpha_{A}^{C}$.

\section{TABLE 2}

$(*) \mathrm{T}^{\mathrm{H}} \cong \mathrm{T}^{\mathrm{C}}+2.0^{\circ} \mathrm{C}$

In the case of urea, molecular sublimation is easy, so we can write $\alpha_{\mathrm{U}}^{\mathrm{s}}=1$. Further, since no biuret is formed in the growing crystal [13], we assume $\alpha_{A}{ }^{C}=0$ for $P_{A}{ }^{C}<\left(P_{A}\right)^{C}$ and $Q_{A}{ }^{C}=0$ for $P_{A}{ }^{C}>\left(P_{A}{ }^{\circ}\right)^{C}$. Due to these simplifications, the unknowns are reduced to six. The two lacking equations can however be given when, by fixing $P_{\text {ext }}, T^{j}$ and $\gamma$, we are able to measure experimentally $Q_{v}^{C}$ and $Q^{H}=\sum_{i} Q_{i}^{H}$. We can write:

$$
k_{U}^{C} S^{c}\left(P X_{U}^{C}-\left(P_{U}^{0}\right)^{c}\right)=\left(Q_{u}^{c}\right)_{E X P}
$$




$$
\mathrm{k}^{\mathrm{H}} \mathrm{S}^{\mathrm{H}}\left(\mathbf{P}-\mathrm{P}_{\mathrm{EXI}}\right) \sum_{\mathrm{i}} \mathrm{X}_{\mathrm{i}}^{\mathrm{H}} \sqrt{\mathrm{M}_{\mathrm{i}}}=\left(\mathrm{Q}^{\mathrm{H}}\right)_{\mathrm{EXP}}
$$

The set of six equations (21), (22), (24), (25) in six unknowns $P, \alpha_{U}^{c}, \alpha_{A}^{s}, X_{U}^{s}, X_{U}^{\mathrm{H}}, X_{U}^{c}$ has been solved making use of the experimental data of Table 2. In the same table, the calculated values of $P$ and $\alpha_{\mathrm{U}}^{\mathrm{C}}(=\alpha)$ are also reported.

\subsection{Comparison with experiments}

Though many PVT growth experiments with urea have been performed $[7,8,13,18-20]$, none of them was planned for a quantitative verification of the present stability model. Nevertheless all experiments points to growth instability in closed configurations and stability in SO configurations for wide ranges of experimental conditions. This stability seems however limited, for a fixed set of growth parameters, to small-size crystals [8]. As also reported for mercuric iodide [21], beyond a certain size crystals tend to destabilize through surface roughening and rounding. This last fact however cannot be explained in terms of an isotropic stability model as ours, as previously

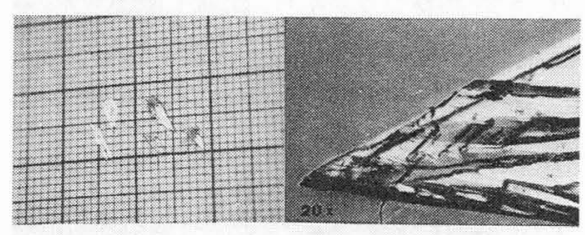

a

Figure 3: Crystals of urea (a) grown in closed ampoules; micrograph (b) of one of these crystals, showing dendritic formation. pointed out $[22,23]$.

Here we limit ourselves to compare our calculations with a few growth experiments for which a semiquantitative estimation of growth parameters seems possible.

A. For the set of $T(0), T(L)$ and $L$ values of Fig.2, closed-ampoule growth of urea was carried out $[13,18]$, and a growth rate of $\mathrm{v}_{\mathrm{U}(\mathrm{s})}=(9 \pm 2) \times 10^{-9} \mathrm{~cm} / \mathrm{sec}$ was measured which fits with $\alpha$ between $0.0001 \div 0.001[13]$. For this experiments $\mathrm{G}_{\mathrm{V}}$ was estimated about $0.1 \mathrm{~K} / \mathrm{cm}$ and the overall pressure was calculated to be about $0.01 \mathrm{~atm}$. This $\left(\mathrm{V}_{\mathrm{U}(\mathrm{s})}, \mathrm{P}\right)$ point in Fig.2 falls in an unstable region, in agreement with microscopic observations of the grown crystals (Fig.3).

B. Urea crystals can be grown by SO-PVT techniques in which the ampoule is pulled with respect to a fixed T-profile [7, 18-20]. This means that both $\mathrm{T}(\mathrm{L})-\mathrm{T}(0)$ and $\mathrm{G}_{\mathrm{v}}$ change with time. We can however estimate $\mathrm{T}(\mathrm{L})-\mathrm{T}(0) \sim 2 \div 5{ }^{\circ} \mathrm{C}$ (at least in the final growth stage) and $\mathrm{G}_{\mathrm{V}} \sim 1 \div 3{ }^{\circ} \mathrm{C} / \mathrm{cm}$. The external pressure $\left(\mathbf{P}_{\mathrm{EXT}}\right)$ has been variously reported between $3.5 \times 10^{-2}[18]$ and $1 \times 10^{-3}$ torr [19] and experimental average growth rate have been measured within $(0.5 \div 7) \times 10^{-6} \mathrm{~cm} / \mathrm{sec}$. Since for these experiments $\mathbf{P}$ inside the ampoule is not known, comparisons with our model cannot be made.

We can however assume the data of Table 2 as typical of SO-PVT processes. With reference to run No.7, we have $\mathrm{P}_{\mathrm{EXT}} \sim 7 \times 10^{-6} \mathrm{~atm}, \mathrm{P} \sim 3.6 \times 10^{-5} \mathrm{~atm}, \mathrm{v}_{\mathrm{U}(\mathrm{s})} \sim 2.2 \times 10^{-6} \mathrm{~cm} / \mathrm{sec}$ and $\alpha \sim 0.025$. The corresponding $\left(\mathrm{P}, \mathrm{v}_{\mathrm{U}(\mathrm{s})}\right)$ point on Fig. 4 (indicated by $\mathrm{A}$ ) shows that under these growth conditions stability is to be expected.

The actual growth experiment, attempted under the above conditions, was carried out at a higher $P_{\mathrm{EXT}}\left(4.6 \times 10^{-5} \mathrm{~atm}\right)$ and hence at a lower growth rate $\left(\mathrm{v}_{\mathrm{U}(\mathrm{s})} \sim 6 \times 10^{-7} \mathrm{~cm} / \mathrm{sec}\right)$ because of a calibration error. In spite of the worsened stability conditions, a stable crystal was grown, as shown in Fig. 5. By estimating $\mathrm{P} \sim 3 \mathrm{P}_{\mathrm{EXT}} \sim 1.4 \times 10^{-4}$ atm, the growth conditions on Fig.4 are represented by point $B$ which still falls in the stable region.

C. High-quality urea crystals have also been grown with a sophisticated facility as reported in [8]. These crystals are characterized by a very high degree of morphological stability until they do not 
exceed a given size. A detailed X-ray and optical characterization of these crystals was also reported $[7,8]$.

Though our model would predict stability for these crystals, the marked anisotropy with $v_{U(s)}$ largely changing with crystallographic orientations and the essentially three-dimensional character of the temperature profile make the present one-dimensional stability model unsuitable for quantitative considerations.

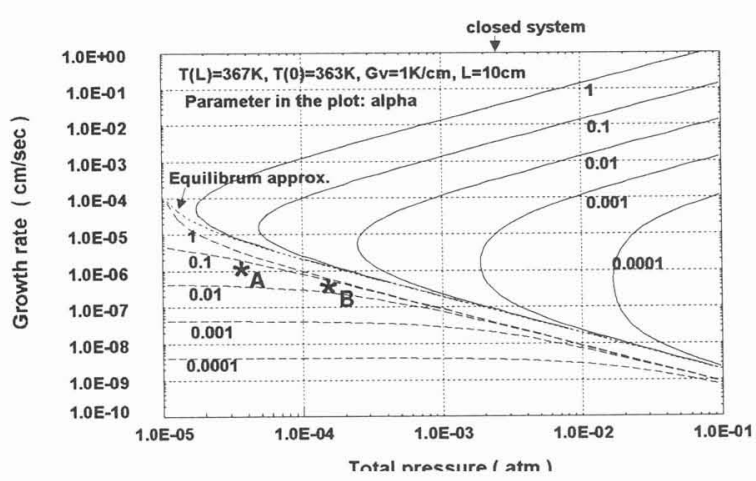

Figure 4: Calculated (dashed curves) and experimental (point A and B) growth rates for typical SO-PVT growth conditions, which fall in the stable region.

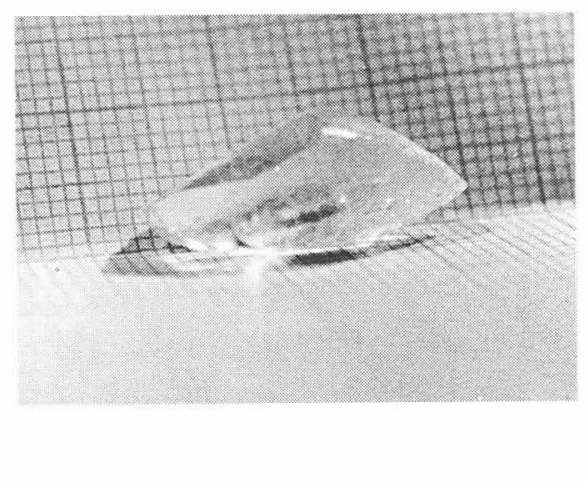

Fig. 5 Crystal of urea grown by SO-PVT (see text); its growth conditions are represented by point B in Fig. 4 . A detailed X-ray analysis of this crystal is given in [7].

\section{CONCLUDING REMARKS}

The stability model presented in this paper appears suitable for predicting stable growth in SO-PVT processes, in which the pressure inside the growth system is reduced with respect to closed systems.

The relaxation of the local-equilibrium assumptions of previous analyses allows for the introduction into the model of stability effects related to kinetical constraints at the growing interfaces. It is shown that stability increases with the increase of these constraints, which are expressed in terms of the crystallization coefficient $\alpha$.

A semiemperical approach to estimate $\mathbf{P}$ and $\alpha$ in SO-PVT growth experiments is further proposed, which enables a quantitative comparison between calculated and experimental growth rates and between them and the critical growth rates of the model.

It should finally be remarked that $\alpha$ in closed systems appears smaller than in SO systems. It can be speculated that (a) by decreasing $\mathbf{P}$ in SO-systems, $P_{\mathrm{U}}(0)$ increases with supersuturation, which means, according to [24], that $\alpha$ should increase and (b) in closed system $\alpha$ is reduced due to a larger content of volatile impurities.

\section{ACKNOWLEDGEMENTS}

The authors are indebted to Mr. Zuccalli and Mr. Attolini for valuable technical assistance. The financial support of the Italian Space Agency (ASI) and INFM are gratefully acknowledged. 


\section{REFERENCES}

[1] Schönherr E., "The growth of large crystals form the vapour phase", in "Crystals", vol. 2 (H. C. Freyhardt ed., Springer, Berlin, 1980).

[2] Rosenberger F., "Fundamentals of Crystal growth form Vapours", in "Crystal Growth in Science and Technology" (H. Arend, J. Hulliger eds., NATO ASI Series, Plenum, New York, 1989).

[3] Paorici C., Per. Mineral. 61 (1992) 47.

[4] Factor M. M. and Garrett I:, "Growth of Crystals from the Vapour" (Chapman and Hall, London, 1974).

[5] Halbout, J. M. and Tang, C. L.: "Properties and Applications of Urea", in "Nonlinear Optical Properties of Organic Molecules and Crystals" (D.S. Chemla and J. Zyss eds., Academic Press, 1987).

[6] Donaldson W. R., "The Growth of Urea Crystals for Use in an Optical Parametric Oscillator", Thesis (1984)

[7] Paorici C., Zanotti L., Zha M. and Franzosi P., "Urea Crystal Growth by Physical Vapour Transport", MRS Symp. Proc., 328 (1994) 125.

[8] Zha M., Franzosi P., Zanotti L., Zuccalli G., Paorici C., Capelletti R. and Razzetti C., J. Crystal Growth, 146(1995) 29-36.

[9] Reed T.B., LaFleur W. J., Appl. Phys. Lett., 5 (1964) 191.

[10] Reed T.B., LaFleur W. J.,Strauss A. J., J. Crystal Growth, 3/4 (1968) 115.

[11] Factor M. M., Garrett I., J.Chem. Soc. A (1971) 934.

[12] Rosenberger. F, Delong M.C., Greenwell D.W., Olson J.M., Westphal G. H., J. Crystal Growth, 29 (1975) 49.

[13] Paorici C., Zha M., Zanotti L., Mucchino C., Attolini G., Traldi P., Catinella S., Cryst. Res. Technol. (in press)

[14] Suzuki K., Onushi S., Koide T., and Seki S.: Bull. Chem. Soc. Japan, 29 (1956) 127.

[15] Bird R. R:, Stewart W. E., Lightfoot E. N. Transport Phenomena (Wiley, New York, 1960) Ch. 16.

[16] Hirschfelder J. O., Curtiss Ch. F., Bird R. B., Molecular Theory of Gases and Liquids (Wiley, New York, 1965) Ch.8

[17] Rutter J. W., Chalmers B., Can. J. Phys. 31 (1953) 15.

[18] Paorici C., "Crystal Growth from Low Temperature Vapour Phase", Proc. VIII European Symp. On Materials and Fluid Sciences in Microgravity, Brussels, 12-16 April 1992, ESA-SP-333, vol.II (1992) p.557.

[19] Feigelson R. S., Route R.K. and Kao T. M., J.Crystal Growth, 72 (1985) 585.

[20] Piechotka M. and Kaldis E., ESA Contract No 5943/83/F/FL, Final Report, Zürich (1984)

[21] Piechotka M. and Kaldis E.,J. Crystal Growth 99 (1990) 1300.

[22] Chernov A. A., Soviet Phys.-Crystallog., 16 (1972) 734.

[23] Xiao Rong-Fu, Iwan J., Alexander D., Rosenberger F., Phys. Rev. A, 38 (1988) 2447.

[24] Hirth J.P., Pound G.M., "Condensation and Evaporation - Nucleation and Growth Process", (Pergamon, New York, 1963) 